\title{
TO BE, TO MOVE, TO REACT
}

REFLECTIONS ON POSSBLLE

NEO-POSTCOLONIAL READINCS

\section{OF THE AFRICAN AGENCY}

DIANA SFETLANA STOICA

DOCTORAL STUDENT

DOCTORAL SCHOOL OF PHLOSOPHY, SOCIOLOGY AND POLITICAL SCIENCE

WEST UNIVERSITY OF TIMISOARA

DIANA.STOICA80@E-UVT.RO

Focusing on African agency, this paper debates around a constructed triad of concepts found at the roots of African ways of expressing the struggle for identification, recognition and also the rise of a continent in worldly discourses, in a holistic and rather philosophical approach. The constructed triad is represented by narratives of dynamic verbs such as to be, to move and to react, in a post-structuralist intent to express the concept of following Africa, an alternative token for the changes in the perception of African agency. The aim of this concept is to symbolize, in a neo-postcolonial reading, the consciousness of self-consciousness, as a possible complex process of African becoming and the African continent's rise in the global narratives.

African agency, neo-postcolonialism, Africa's rise, following Africa, self-consciousness 


\section{Introduction}

This reflection is meant to briefly explore the foundations and types of African agency. The methodology used is the joining of conceptual representations that African agency assumed throughout the years from the fifties to the present day, with a holistic philosophical approach to some critiques of each period. While joining these elements, the key concepts followed are a) to be, or being; b) to move, or movement; and c) to react; all systematically entrenched with the African agency. Besides giving an alternative of their relations in the context of African agency, this study proposes an alternative token for the changes in the perception of it, namely following Africa, which would mean the consciousness of self-consciousness. One step towards the creation of it, is, in the view of this paper, the moral agency and the moral $r$ (evolutions), terms instrumentally used within pragmatic definitions in order to simplify and highlight the conclusion on possible trends of discourse on following Africa.

\section{Key issues on the neo-postcolonial choice}

Although much attention was given to agency and leadership in the shaping of the African continent's development perspectives, in the African or Africanist writings, the subject is still open to debates as to whether changes in the polarization of the world have participated or not in a reshaping of these perspectives. Moreover, if writers, philosophers, political analysts, economists, or historians would agree to unify their works on the perspectives of transformations in the African society, with a unanimous purpose to deconstruct such stereotypes like poverty, insanity, primitivism, security risks, that accompany the image of Africa in certain domains of First World's social life, migration included (Tarrósy, 2014: 17), they would be in front of a frosty winter, forcing them to put on new jackets and re-read the African agency in the new context. The aim here is to analyze whether these jackets exist and are not like the "Emperor's new suit".

Re-reading the African agency from so many perspectives would be, with no doubt, a very long and exhausting process. Thanks to development studies some of the mentioned fields have found a good ally to have their interests defended. Since development studies look where each and every other field of study separately taken refused to look (Kapoor, 2008: 3). Valuing the idea of the relativization of paradigms (Slater, 1992: 294) and the demand if thinking in terms of paradigms is appropriate (Pieterse,1998: 344), the focus of development studies on the African issue and African agency was realized in the contested key of a "genuinely" postcolonial viewpoint, as a political (dis)engagement to relations of power in the colony and neocolonialism, functioning in certain geographical and political contexts (MooreGilbert, 1997: 10).

A necessary turn in this regard would be the neo-postcolonial vision, seeing that, from an African philosophical perspective, the "post" of the "post" colonial should be written in brackets, as the achievements of the African overall independence starting from the sixties had not fulfilled the African dream (Eze, 1997: 14). Or, 
considering that "post" from "postcolonial" would be different from any "post" in other formulations, would not refer to domination from colonizer on colonized anymore, but would have moved in both directions (Ahluwhalia, 2001: 92).

Such neo-postcolonial proposition would keep the gaze onto a new type of colonizer, to probe not only the Western knowledge's production as in the case of Gayatri Spivak's post-colonialism (Kapoor, 2008: 55), but also the deconstruction of the West and its produced knowledge, in line with western philosophers such as Michel Foucault and Gilles Deleuze, criticized by Gayatri Spivak (Kapoor, 2008: 54). On the other hand, Africa itself is a victim of the broader objectification of its own postcolonial discourse, as African states became victims of their postcolonial regimes (Bell, 1997: 206). Therefore a neo-postcolonial view would like to assess the perspective
Although much attention was given to agency and leadership in the shaping of the African continent's development

perspectives, in the African or Africanist writings, the subject is still open to debates as to whether changes in the polarization of the world have participated or not in a reshaping of these perspectives.

which sustains the development discourse able to reconsider, criticize or build the new African society (cultural relativism on the purpose and only for this reason being accepted), or the post-postcolonial and postmodern one.

In terms of development policies and political studies, the post-postcolonial turn would be reflected in the idea shared within the African and Africanist discourse that a more strategic approach of the African governments in international relations and development would ease a reply to the question on what would be actually good for the Africans, given by the Africans themselves (Tarrósy, 2011: 27).

\section{Agency in a time of Africa's rise}

The notion of "agency" was largely defined among scholars of politics, philosophy, even historians. It presumes the resistance, as it encompasses a capacity to act within and against social structures (Jensen, 2011: 66) in the frame of the structure-agency debate (Bleiker, 2004: 9), or willingness and opportunity (Friedman-Star, 1997: 129), analyzed on a discourse-agency axis (Bleiker, 2004: 11). On the other hand, the agency is the capacity one individual has to desire and act for the removal of any type of freedom limitations that might jeopardize his capacity to exercise choice and opportunities, to exert his reasoned agency, as in a paradoxical return from agency to agency envisaged by Sen's capability approach for individual development, at the center of the "development as freedom" paradigm (Sen, 2000). 
According to Jensen, the agency, as resistance, bears two forms: capitalization and refusal (Jensen, 2011: 6), which does not only place the individual at the center of all premises, reframing the bottom-up politics intended as civil society (Kostovicova-Bojicic-Dzelilovic, 2011: 96), but also opens the path for a discourse on values. This happens since capitalization and refusal would mean the non-acceptance to be devalued or the escape from the uniformization through value difference forced reductions (Jensen, 2011: 6).

Further on, in the context of agency in Africa, it would be relevant to assert the connection between values and ideas, as well as ideologies. Although in the first worlds, Third World is seen as preferring "bread", it is relevant to observe, taking into account Amitav Acharya's support of Donald Puchala's argument, that in the Third World ideas and ideologies would be far more important than power or wealth, due actually to the scarcity of power detention and unequal wealth distribution in the world (Acharya, 2018: 20). Along with this view, the question of agency in a historical moment when the African states register important improvements in regards to the place and role on the stage of international relations (relevant increases in the economic growth - e.g. DRC, Ivory Coast, Mozambique in 2015-2016, the membership in symbolic alliances e.g. South Africa in the BRICS, etc.) bring about the concern on the new forms of the agency or on the tendencies and links between agency and leadership.

Such concerns are articulated in a rather holistic definition of an African agency as the long, but successful and uninterrupted way from being the hopeless continent towards being a rising one, in which African voices do believe (Tarrósy, 2020: 73).

One question to encompass the research objective included herein would be whether forms of agency characteristic to the colonial period and represented by the anti-colonial movements should be again represented in the African continent today. Or, which forms of agency are in act. The philosophical approach to this would be the critical analysis of the meanings of Being, in its dynamic facets, or the African meanings of the verb to be, which are analyzed using a qualitative approach.

Looking into works of African writers and Africanists on the concept, an important characteristic and tendency of African agency should be represented by the rhetoric of the agency itself, meaning the narrative of actions taken by the agents and described through both their movement and reactions. In this view, the agency should not be related to leadership, as it would be defining no special individuals, but any individual and all individuals at the same time. This would be the freedom as discoursive control theorized by Pettit, namely freedom as the capacity of a person to have a discursive status in relation to others (Pettit, 2001: 103). In this line, African agency is different and changed in relation to the moment the project of decolonization had initiated and continued, along with the concrete definition of freedom and consciousness of any African state's citizen. The agency was reshaped based on achieved freedom statuses.

One of the limits of such consciousness is the question of African elites or leaders who would encourage neo-colonialism according to Franz Fanon and even Kwame 
Nkrumah (Langan, 2018: 160). For these elites, freedom of the self would be itself diminished due to the impossibility to avoid "weakness and allusiveness" that would hinder the ownership of Africans on their discourse or the chance of discursive relations with others (Pettit, 2001: 103).

Focusing on 'Africa's rise' and the realization of some decolonization purposes in relation to the position in the world narratives and on an international relations stage, the new agency would be represented by the alignment to a global discourse that defines Africans as speakers on various important issues such as poverty reduction (which is not only an African problem), sanity (which is mostly not an African issue and in this the Coronavirus pandemic had shown us how developed countries are facing difficulties), safety, and environmental protection.

In fact, a similar African agency had started first with Pan-Africanism, expressed moreover in arts and creativity (Ifekwe, 2018: 256) and the Négritude movement inspired by the decolonization projects envisaged by Aimé Cesaire. The Négritude, according to Cesaire, would have not been limited to the creation of independent nation-states (Cooper, 2005: 411) able to become single actors on an international relations stage, but would have gone beyond its aim and touched the very transformative possibilities of the colonizer's society. Embracing Négritude as a movement, Fanon also would have gone beyond its interpretation as a simple struggle against colonialism, or a class struggle, as Sartre would have assimilated it (Moore-Gilbert, 1997: 177).

From the appearance of agency present in Fanon's imprecations for all to recognize that the white man would not be more a man than the Negro and every consciousness should be wide open to the simple being (Fanon, 1967: 181) to the process of "Africanization" in the view of Achille Mbembé, the African agency represents the set of discursive frames of reparation, restitution, and justice, departing from the name of "Africa" (Mbembé, 2017: 54). Although Mbembé refers to this while recalling our world is still a world of races (Mbembé, 2017: 55), African agency in the new era of polarization tends to focus its narratives on the fact of extended leadership and its soft power, along with the inclusive and sustainable regional development discourses. On the other hand, the rhetoric of the agency is conciliable with the dimension of "facing forward" as it was expressed in the words of president Nkrumah when asked about his intentions to face the West or the East in his politics (Benyera et al., 2020: 10).

In line with this facing forward and post-positivist turning in the forcefully proclaimed "African reason" (Mbembé, 2017), African agency would represent the shiny part of a becoming that allowed frustrations debated on a psychological structural path by Fanon when talking about the sexual image of the black man (Fanon, 1967: 53), or about the socially created consciousness of ethnicity (Fanon,1967: 122), or even the "grotesque" and "generally obscene emulation of European" (Fanon, 2004: 239), as well as that about the frustration of being isolated by African realities as a trait of colonialism present in the discourse of Amilcar Cabral (1973: 62), to be tempered and turned into grounds for identity building and defending, such as the "Black Lives Matter" (BLM) (2013) gone on the streets and virtually. 
Now the contention of the BLM movement in an African agency context would be per se polemical, due to the context of it. It is a reaction to unjustified violence and crime that falls under racist actions. But, as "not all Blacks are Africans and not all African are Blacks" (Mbembé, 2017: 12), to speak of Africa is to "invoke" Blackness (Mbembé, 2017: 38), as much as the correlative of Blackness invoking Africa would be true, due to both being signs of alterity, hard to assimilate in a western world (Mbembé, 2017: 38).

Therefore, the agency would be the struggle for life and identification, scramble for its own domains of discourse (unlocked from the East or West or even East-West struggle paradigms) and desire for centrality. Moreover, it would be the desire and struggle to become part of a real dialogue with the more industrialized regions of the world, that started with the formation of alliances taking inspiration from the Non-Aligned Movement (Tarrósy, 2011: 18).

While the struggle for life is reflected in the BLM slogan, as fulfilling the frame of identification as a Black and as an African in the end, the scramble for own domains of discourse and the centrality are pillars of discovery agency and the agency of consciousness over the discovered (Nyere, 2020:131), displacing the attention from Africa as an object, to Africa as a subject of its development, being and forward-facing.

On the other hand, the struggle for own domains of discourse was supported by African voices sustaining the freedom of literature, arts and cinema, and briefly the knowledge, in the African languages, without causing any isolation. As Ngugi Wa Thiong'O asserted: "The peasantry saw no contradiction between speaking their own mother-tongues and belonging to a larger national and continental geography" (Thiong'O, 1994: 23). Although Thiong'O wrote about the decolonization of the mind at the beginning of the eighties already, giving credits to language and cultural universal interdependencies and re-asserting the foundations of humankind by considering its language a unique one, the "language of struggle" (Thiong'O, 1994: 108), this topic continues to be a bias, today.

The fear of not having assisted to the complete decolonization of the mind, namely to the total liberation of knowledge production forms is translated into the preoccupation that social change in Africa would be still dominated by the interests of metropolitan forces (Lumumba-Kasongo, 1999: 8), into the suspicion to view modernity as an agency of domination (Adejumo, 2002: 175), or into the ways and forms to reconsider the transformations that are inherent to the so-called African Renaissance. With reference to it, this would be the struggle to coin and sustain an African identity, but mostly an African consciousness, in the rhetoric of the former President Thabo Mbeki (Bongmba, 2006: 294).

For Achille Mbembé, in fact, the notion of "agency" is amassed with notions of "hegemony", "moral economy" and "resistance", endlessly summoned, which have contributed to the rediscovery of a subaltern subject (Mbembé, 2001: 5) or a translated sub-culture of Africanité in the modernity of France and beyond (Eze, 2001: 116). All premises to rediscover them were created and maintained in advance 
by Négritude representatives. For example, one of the fathers of Négritude, Leopold Senghor would have contributed to radical politics and critical social theory to prove the incessant "overlapping, interlocking and intersecting" nature of both racism and colonialism (Rabaka, 2016: 3), because of the supported essentialist particularism in treating the African as different. By such, he was treated in a register of inferiority and servitude, constructing the Africanité as the Other, finding itself outside the Otherness projected by Europe and being negative to the own positivity of the last one (Serequeberhan, 1994: 52). But, at the same time, Négritude was seen as a practice to translate this Africanité into a cultural presence.

Indebted to change this old view and reconstruct the Africanité, the African agency was revealed through the movements recorded as "Ethiopianism, Garveyism, Negritude, Pan-Africanism, African Socialism, African Humanism, Black Consciousness Movements and African Renaissance." (Ndlovu-Gatsheni, 2015: 488). This reconstruction of Africanité or re-Africanization as "return to the source", in the conception of Amilcar Cabral (Serequeberhan, 1994: 102) is strangely linked to the post-structural deconstruction of Jacques Derrida, although in very different periods of time and in a context where, curiously, the primacy would be this time in a non-Western register of thinking. Colonization would mean, for Cabral, the suspension of history for the colonized, meanwhile decolonization a taking over from where it was left (Serequeberhan, 1994: 103).

In criticizing this view that would annihilate history even in reference to the existence and importance to reassert "African-ness" 2 , the African agency sustained by contemporary thinkers on the path opened by Mbembé, refers to a pragmatic struggle on defining Africa as a sign or chimera but also, in the view of this paper, a more romantic agency on following Africa. It is suggested by Africa's "moving in several directions at once", being said on it that "at the same time, [it] has been, is not yet, is no longer, is becoming" (Mbembé, 2001: 241). Further on, while holding a postmodernist direction of discourse, especially on the inclusive development, the paradigm on the agency would function contextually, using adapted ways of being and doing (Rapley, 2007: 209; de Sousa Santos, 2018: 296). Therefore, any conceptualization on African agency would be most fitted in an African ontology, since any ontological difference determine an epistemological one (de Sousa Santos, 2018: 20). However, such a one-way perspective would not allow a connection between studies, by harnessing the

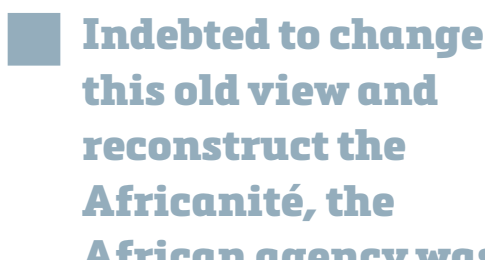

African agency was revealed through the movements recorded. as "Ethiopianism, Garveyism, Negritude, Pan-Africanism, African Socialism, African Humanism, Black Consciousness Movements and African Renaissance." 
work on differences that in scholarly practice would have helped imperial paradigms to be undercut and in reference to narratives of Africa from the inside, to sustain the sameness-as-worldliness (Mbembé-Nuttall, 2004: 351).

Hence, the aim of these reflections is to look into the pillars of the agency from a philosophical standpoint and create an alternative image on the causes and modalities of African agency, through a holistic critical analysis. These pillars would be, therefore, the being, the moving (like mobility or acting) and the reacting, representing the subject, the dynamic objects of the agency and finally the relations between subject and objects, which are often no less than relations of power. In other words, African agency is defined departing from the cumulative post and after-post colonial lenses, based on the proposed pillars, although the intention of this paper is not to impose any definition.

\section{3. "Following Africa" and the three pillars of African agency.}

The narratives of subjects, objects, and the relations governing them are focal points to postmodern social and humanist studies. A re-reading of them in the context of a more contemporary aim and cliché such as that of "following" is not casual, invoking the social media relations structure. In the more liquid society of today, this verb is necessary and relevant. The narratives of debated realities should be created and sustained around this concept if considering the verb "following" as more than "discovering" or "unpacking" but less than "being manipulated" by any influencer.

In the words of Bonaventura de Sousa Santos, emancipatory acts, meaning the expression of agency in the Global South, might not follow the Eurocentric scripts (de Sousa Santos, 2018: 298). For this reason, there is much to suppose that own receipts of the Global South are followed from within it, with consciousness with regard to the gained self-consciousness, $65+$ years after the Bandung Conference. Hence, while unpacking resistance, emancipation, self-consciousness and reconciliation mechanisms that played an important role in the becoming of Africa and the definition of consciousness on an African Self, conceptualizing the $21^{\text {st }}$ century's Africa following would mean the consciousness of Africans to pursue the awareness of their value ${ }^{3}$ and declare it to the world.

Since the concept of "following" is sustained in contemporaneity, due to social media expansion, the fact of pursuing or having a so-called conscious way to declare the self-consciousness in an African context is linked to this fluid opportunity of getting out from a sort of marginalization. The foundations of this process are still to be analyzed in the context of power relations, given by the positionalities of media products in a neo-liberal rationale. In this context "following Africa" could represent a new form of agency developed to transform the relations of power or the perceptions on them in an African narrative, taking inspiration from one of the main questions of contemporary philosophers, if there are margins to "talk about moving beyond colonialism?" (Mbembé, 2001: 237).

Returning to the notion pillars of being, moving, and reacting, representing the subject, the object, and their relations, the axis of a new agency discourse based on 
the "following" concept should have its first and most important reference: the being or the subject in the absence of which, no discourse could take place. Considering that the ubuntu essence of "I am because you are", describing the co-existence and co-being in a South African community (de Sousa Santos, 2018: 10), is nearly completely embraced in overall African narratives as a hint and pattern, the definition of being, as "being African" and "being Black", was developed during centuries of academic or non-academic discourse by still bringing up the memory and development of the colonial relations with Europe and concomitantly, the metamorphoses of race. As Mbembé states: "The notion of race made it possible to represent non-European human groups as trapped in a lesser form of being." (Mbembé, 2017: 17).

On the other hand, the becoming of being is linked to the idea of self-consciousness and the achievement of humanity through the formulation of basic "I think therefore I am" of Descartes and "I am conscious to myself" of Kant, which contributed to the racialization of man and culture (Eze, 2001: 9). Meanwhile the construction of the I was in act, this racialization assured the organization of the world in fixed groups, with limitations and the scarce possibility of movement between groups, as in the logic of an enclosure (Mbembé, 2017: 35). This entrenchment between being and moving, or to be and to move, shows the circularity sustained already in Towa's approach on reason and freedom that truly existed only in the Self (Towa, 1971: 17). It is in this view that freedom, including that one to move, might philosophically point the movement towards one-self, the freedom to be free to know one's self, so follow the completion of its consciousness.

Likewise in Towa's circularity, the connection between to be and to move in the key lecture of this direction would place to move in the area of conceptualization of a critical return to the African-ness, namely to the precolonial history or to the essence of being and the culture of the colonized, such as the notion of decolonization have been defined by Franz Fanon (Rabaka, 2009: 126). This kind of return would have tried to force the abyssal line of color between Africans and Europeans in the considerations of the pan-Africanist W.E.B. Du Bois (Rabaka, 2009: 114), but also the one between humans and sub-humans (Benyera, 2020: 12), or the being and the non-being zone imagined by Fanon in the form of freedom achievement (De Sousa Santos, 2018: 20).

As Jean-Paul Sartre had argued, one of the important secular African agencies - The Négritude movement - would have been a reaction of "alienated Africans to European racist and capitalist cultures" (Eze, 2001: 157). The Black Consciousness movement having taken the scene after the sixties, focused, instead, on the "reactionary spirituality of pacifism", that would have shattered the authenticity of reactions to pursue the humanity achievement (Mdingi, 2020: 182). Consequently, the instrumental concept of to react, as the third pillar of the following Africa construction, would be an opposite to the movement towards the liberation from the status of colonized and the creation of being. But, on the contrary, in the actual African narratives, to react is seen as a necessary action taken by the ones controlled (Nyere, 2020: 152), so it co-exists with to be and to move as described above, in a normal estate of questioning the Self, from different positions. 
On the African subjectivity, endorsed by the verb and the action of to be, there is endless literature, starting from philosophy to political studies, including international relations, where the discourse of the African agency appears more effective but more questionable (Tarrósy, 2011; Tarrósy, 2006). In this regard, the completion of the picture with to move, should be necessarily done. This idea is supported by the landscape of non-passivity of the African agents (more generally, the states) in international relations (Chipaike \& Knowledge, 2018: 11).

In the conceptual scheme proposed herein, to move becomes a correspondent of the object as it reflects a consequence of to be, or the subject. Phenomenologically speaking no object exists without the subject creating it continuously and in a dualistic perspective, the movement, as an object, represents a series of positions [that the subject adopts in order to construct the reality] (Bergson, 1969: 9). These positions are positions of power as in a colonial context, where subject and object positions are incompatible (Williams, in Falola Jennings, 2002: 279).

Besides, to react, as an expression of relations between the subject and the object, or to be and to move, reflects the power of the concept to move over to be. If to move understanding is to direct the being towards one's Self, to react to this movement signifies a displacement, hence a reinforcement of movement or resistance to it. The reinforcement of movement is given by a pragmatic view sustained, among others, by Achille Mbembé and Sarah Nuttall when talking about the African continent's interstices, the emplacements, and displacement (Mbembé \& Nuttall, 2004: 351). In this view, Africa as an object is a space in motion. The displacement contributes to the maintenance and direction of it and the view should be considered at a macro level. On the contrary, if displacement is seen as resistance to the movement towards the self, at a micro level, this would support Achille Mbembé's opinion that the colony is the displacement between the self and the subject (Mbembé, 2017: 105).

In a postcolonial analysis of the be-move-react triad concerning African agency, primacy it is given to a new $21^{\text {st }}$ century's proposition of the identity. Secondly, the consciousness of this identity is being unpacked into mobility towards the Self abstracted from the various facets of mobility. Thirdly, it laps around the orientation of this consciousness, as the relation between the identity created and the image of it created for the others. In this triad, the mobility is the completion of African contexts and discourses motions, but summarizing, the creation of rights to have rights (Benyera, 2020: 12). The last element of the triad, namely reaction, or the relationship between identity and its image refers to the way the subject might react to the environment, therefore, guide the motion and place it in relation to the being (slipping towards it or not).

\section{The be-move-react triad and the moral African r(evolution)}

Recorded as an important reference to this analysis, the development and the justice are endings of the African moral agency, for which a moral revolution should be necessary (Benyera, 2020: 14). At this point, Franz Fanon's discourse of the fifties, from his book "Black skin, white masks", according to which blackness is immorality in 
the imagination of the whites (Sardar, intr. Fanon, 2008: xiii) seems to be continued, if we consider the image of African states in the world, as less democratic and corrupt. In this case, the moral agency was linked to leadership in the contemporary debate over democracy and even corruption.

Actually, moral evolution was a special concern for an important number of scholars in African affairs in the fifties (Mudimbe, 1988: 52), not unexpectedly from Europe. This would have led to several polemics on the position of power the Eurocentric thinking could have occupied in relation to the evolution or transformation of African society.

One of the anthropologists recalled by Mudimbe was Marcel Griaule (1988: 52). Although Griaule had contributed to the capitalization of African philosophy in his book "Dieu d'eau", while exposing some worldviews of Dogon people (living on the territory being part of today's Mali) and having added knowledge and image to an overall African philosophical picture initiated with the work of Placide Tempels on Bantu people (central and southern parts of the African continent), some African critiques suggested that he or his research colleagues could have fabricated some dialogues of his interlocutory, Ogotemmeli (Wiredu, 2004: 100) in order to create a reality for Africa rather than unpack it. The preoccupations of Griaule for the moral evolution would thus be of support to Eurocentric thinking and all thesis of primitiveness in Africa on one side, but also an acknowledgment on the moral state at that time. Both Griaule and Tempels believed in the potentiality of African culture, even if enclosed in a sort of pure metaphors that the world views of Bantu and Dogon people separately offered to the European researchers. Both anthropologists considered that colonization was an accident, with historical benefit (Mudimbe, 1988: 80).

Instead, after the fifties, precisely after the birth of Négritude, Black Personality Movement and the new "thinking subject", as the African philosopher was defined by Paulin Hountondji (Mudimbe, 1988: 51), other philosophers, like Obenga and Mveng, were talking about the moral benefit of Africa as the cradle of humankind (Mudimbe, 1988:110). Meanwhile, Kwasi Wiredu refers to morality as the harmonization of interests into the community and a "fragile endowment of the human psyche" (Wiredu, 2004: 18), highlighting the frequent incorrect confusion with ethics.

Morality, defined in the context of a discourse on the moral revolution, represents "a code of conduct that, given specified conditions, would be put forward by all rational persons" (Benyera, 2020: 14). Considering Ali Mazrui's conclusion that what Africa knows about itself, or any part of Africa [regions and states] know about each other was influenced by the West (Ndlovu-Gatsheni, 2015: 486), also, the state of morality and its evolution should be necessarily included in a logic of Euro-American-centric view. With this, the constructed triad be-move-react, reflects an actual discourse on the necessity of the moral revolution, from the age of African asserting the being to the move towards the Self and a moral reaction to the exterior. This moral revolution is depicted by Achille Mbembé as an urge to make Africa unique, being a moral and political problem (Mbembé, 2002: 255). In this view asserting the 
being is concretized in the movements of identity such as all movements related to race and color.

It was Fanon who pictured the image of the "Black" ("Negro") in the eyes of the westerner, going beyond that one of the "African", built by earlier anthropologists like Temples and Griaule. For Fanon, the image of the Negro in this frame was beyond any morality and prohibition (Fanon, 1967: 136). Referring to Bantu, as an expression of an "African" discovered by the West, he pointed on its created image as being without a Being, with existence in non-being and imponderability (Fanon, 1967: 143). At the same time, Fanon claimed for the Negros to be "dropped", in order for them to regroup their authentic forces, which could have meant the claim to a segregation of studies (researches on Africa) that would have diminished the agency with the weakening of whichever element of the triad.

Further on, while decolonization was in progress, African intellectuals produced the metanarrative of movement towards the Self, which previously, under colonization, was not even recognized by the self, besides by the Other (Mbembé, 2002: 241). Such movement, in this view, has no end, being part of the moral (r)evolution, defined as such due to double definition of morality as status and process, namely the status of moral evolution preoccupying the Eurocentric thinkers in the past and the moral revolution preoccupying the African scholars in the present. Such definitions reflect the continuum of a movement reflected constantly in the African culture.

The third element of the triad or the third pillar of the "following Africa" assembly is signified by to react. It also embodies the " $\mathrm{r}$ " from $\mathrm{r}$ (evolution), bearing very distinct approaches, of status or process, in other terms, of opposite reaction to the move towards the self or the propping up of it. This is reflected in the dominant African discourses on the self, placing race at the foundation of morality and their more actual inversions, trying to annihilate the traditional dichotomies (Mbembé, 2002: 257). But, also, the reaction in the descriptive repository of the be-move-react triad is the adaptation to the environment, a trying to move away from the old directions of going towards the Self on a predefined road, so that ,anyone can imagine and choose what makes him or her an African" (Mbembé, 2002: 258). Or, from an international relations perspective, the be-move-react triad expresses the gradual arriving of African states to a position of choice between different apparently antagonistic proposals of the North and the South (Tarrósy, 2011: 18).

This type of image fracturing, the reaction to old paths and paradigms, could only take place in a context where, as hypothesized in this paper, there would be a constant following of Africa, from beneath and beyond, with a particular attention to not defend a pan-Africanistic view, but rather a conceptual and de facto federalization, especially in regards to the creation of stronger and interest driven country unions between those who share much of the culture, traditions, and language that unpack Africa (Tarrósy, 2006: 391), while assure the continuation of its rise and recognition. 


\section{Conclusions}

Having in mind Mbembé's contribution to today's philosophy, but also his critique and attention to currents that have tried, with more or less success, to explore and empower the symbols of an African collective imaginary (Mbembé, 2002:239), the aim of this paper was to use and adapt three general symbols of being-moving-reacting, in order to describe the reality on the African agency, viewing the changes and the new directions of evolution. Translating "being", "moving" and "reacting" into the subject, the object, and their relations, the intent was to highlight, on one hand, the transfer from subjecthood to objecthood as a premise and end of colonization, the necessary return, or the move towards the Self. This would be the movement of the object in a process of following itself and last but not least, the relations between them as both participants to a reactionary adaptation to global and holistic changes of contexts and discourses.

The metaphor of following is the contextualization and maybe forceful drafting into contemporaneity. It is reflected in the continuous return to Africa's identification issue, which is observed in various forms and periods but takes different forms from the previous ones, with the temptation to design and close a circle. This concept is also signified in the idea of moral r(evolution) which launch the invitation to attentively look into the idea of status and process. The interpretation used herein allows evolution to be considered a status, case in which revolution is necessarily a process, but $r$ (evolution) is the combining of them with the intent to root the stereotypical premise of African backwardness out from a chronological axis.

In this way, the African continent would be pictured on a continuum of normal evolution, having the dynamic status vacillating based on impulses of discursive returns and the sum of all discourses represent the process, id est the actual revolution, or the following Africa framed in a differently but not totally estranged conceptualization of the African agency.

\section{Notes}

1 according to data taken from IMF World Economic Outlook, October 2015, Africa's economic growth. Taking Off or slowing down, EPRS | European Parliamentary Research Service Author: Ionel Zamfir Members' Research Service January 2016 - PE 573.891, https:/www. europarl.europa.eu/RegData/etudes/IDAN/2016/573891/EPRS_IDA\%282016\%29573891_ EN.pdf

2 own translation to Africanité, from French

3 the term, „value" is used in its sense of worth, merit; 


\section{References}

- Acharya, A. (2018). Constructing Global Order: agency and change in world politics. Cambridge University Press.

- Adejumo, C. (2002). African Art: New Genres and Transformational Philosophies in Falola, T., \& Jennings, C. (2002). Africanizing Knowledge. African Studies Across the Disciplines. New Brunswick: Transaction Publishers, pp 165-190

- Ahluwalia, P. (2012). Politics and post-colonial theory: African inflections. Routledge.London, UK and New York, USA.

- Bell, R. H. (1997). Understanding African Philosophy from a Non-African Point of View: An Exercise in Cross-cultural Philosophy in Postcolonial African philosophy: A critical reader. Blackwell Publishers Ltd, 1997, Massachussets USA and Oxford, UK, 197-221.

- Benyera, E., Francis, R. \& Jazbhay, A. H. (2020). Challenging Discourse and Searching for Alternative Paths: Justice, Human Rights and Leadership in Africa. In Reimagining Justice, Human Rights and Leadership in Africa Springer, Cham, 3-20.

- Bergson, H. (1969). La pensée et le mouvant: essai et conférences. Presses Universitaires de France.

- Bleiker, R. (2000). Popular dissent, human agency and global politics (Vol. 70). Cambridge University Press, Cambridge, UK.

- Bongmba, E. K. (2004). Reflections on Thabo Mbeki's African Renaissance. Journal of Southern African Studies 30 (2), 291-316.

- Cabral, A. (1973). Identity and dignity in the context of the national liberation struggle. Return to the Source, 60 .

- Chipaike, R. \& Knowledge, M. H. (2018). The question of African agency in international relations. Cogent Social Sciences 4 (1), Article 1487257.

- Cooper, F. (2005). Postcolonial Studies and the Study of History in Loomba, A., Kaul, S., Bunzl, M., Burton, A. M., \& Esty, J. (2005). Postcolonial studies and beyond. Duke University Press, 401-423.

- De Sousa Santos, B. (2018). The end of the cognitive empire: The coming of age of epistemologies of the South. Duke University Press.

- Eze, E. C. (1997). Introduction: Philosophy and the (Post)colonial in Postcolonial African philosophy: A critical reader. Blackwell Publishers Ltd, 1997, Massachussets USA and Oxford, $\mathrm{UK}, 1-23$.

- Eze, E. C. (2001). Achieving our humanity: The idea of the postracial future. Psychology Press.

- Fanon, F. (1967). Black skin, white masks, CL Markmann, Trans.

- Fanon, F. (2004). The wretched of the earth (R. Philcox, Trans.). New York: Grove. (Original work published 1961).

- Friedman, G., \& Starr, H. (2002). Agency, structure and international politics: From ontology to empirical inquiry (Vol. 2). Routledge.

- Ifekwe, B. S. (2018). Black creativity in Jamaica and its global influences, 1930-1987, in Adelakun, A., \& Falola, T. (Eds.). (2018). Art, creativity, and politics in Africa and the diaspora. Springer, 247-266.

- Jensen, S. Q. (2011). Othering, identity formation and agency. Qualitative Studies 2 (2), 63-78.

- Kapoor, I. (2008). The postcolonial politics of development. Routledge, New York, USA

- Kostovicova, D., \& Glasius, M. (Eds.). (2011). Bottom-up politics: an agency-centred approach to globalization. Springer.

- Langan, M. (2018). Neo-colonialism and the poverty of 'development' in Africa. Palgrave Macmillan.

- Lumumba-Kasongo, T. (1999). The dynamics of economic and political relations between Africa and foreign powers: A study in international relations. Greenwood Publishing Group. 
- Mbembé, A. (2001). On the postcolony (Vol. 41). Univ of California Press.

- Mbembé, J. A., \& Rendall, S. (2002). African modes of self-writing. Public culture 14 (1), 239-273.

- Mbembé, J. A., \& Nuttall, S. (2004). Writing the world from an African metropolis. Public culture 16 (3), 347-372.

- Mbembé, A. (2017). Critique of black reason. Duke University Press.

- Mdingi, H. (2020). Pharaoh Let My Children Go: Meditations on Blackness Under Democratized Whiteness. In Reimagining Justice, Human Rights and Leadership in Africa (pp. 179-194). Springer, Cham.

- Moore-Gilbert, B. J. (1997). Postcolonial theory: Contexts, practices, politics. Verso Books. London and New York.

- Mudimbe, V. Y. (1988). The Invention of Africa: Gnosis. Philosophy, and the Order of Knowledge 27, 191-92.

- Ndlovu-Gatsheni, S. J. (2015). Decoloniality as the future of Africa. History Compass 13 (10), 485-496.

- Nyere, C. (2020). NATO's 2011 Invasion of Libya: Colonialism Repackaged? In Benyera, E., Francis, R., \& Jazbhay, A. H. (2020). Challenging Discourse and Searching for Alternative Paths: Justice, Human Rights and Leadership in Africa. In Reimagining Justice, Human Rights and Leadership in Africa (3-20). Springer, Cham, 123-158.

- Pettit, P. (2001). A theory of freedom: from the psychology to the politics of agency. Oxford University Press on Demand.

- Pieterse, J. N. (1998). My Paradigm or Yours? Alternative Development, Post-Development, Reflexive Development, in Development and Change Vol. 29, Blackwell Publishers Ltd, 343373.

- Rabaka, R. (2009). Africana critical theory: Reconstructing the black radical tradition, from WEB Du Bois and CLR James to Frantz Fanon and Amilcar Cabral. Lexington Books.

- Rapley, J. (2007). Understanding Development: Theory and Practice in the Third World, Lynne Rienner.

- Sardar, Z. (2008). Introduction to Frantz Fanon Black Skin, White Masks.

- Slater, D. (1992). Theories of Development and Politics of the Post-modern - Exploring a Border Zone, Development and Change 23 (3), pp 283-319.

- Sen, A. (2000). Development as freedom. Development in Practice 10 (2)

- Serequeberhan, T. (1994). The hermeneutics of African philosophy: Horizon and discourse. Psychology Press.

- Tarrósy, I. (2006). Kelet-afrikai Föderáció: álom vagy valóság? In: Sebestyén, É., Szombathy, Z., \& Tarrósy, I. (Eds.). Harambee: Tanulmányok Füssi Nagy Géza 60. Születésnapjára, Pécs, Publikon Könyvek, ELTE BTK Afrikanisztikai Oktatási Program, 384-393.

- Tarrósy, I. (2011). New South-South Dynamics and the Effects on Africa, In: Tarrósy, I., Szabó, L., \& Hyden, G. (Eds.). The African State in a Changing Global Context: Breakdowns and Transformations, London, Vienna, Münster, LIT Verlag, 17-33.

- Tarrósy, I. (2014). Elméleti megfontolások a nemzetközi migrációs tendenciák megértéséhez, In: Tarrósy, I., Glied, V., \& Vörös, Z. (Eds.). Migrációs tendenciák napjainkban, Pécs, Publikon Kiadó, 9-25.

- Tarrósy, I. (2020). 2020, Afrika. Az „Afrika felemelkedőben” narratíva valósága. Máltai Tanulmányok 2 (1), 71-81.

- Thiong'o, W. (1994). Ngugi. Decolonising the Mind. 1987. Harare.

- Towa, M. (1971). Essai sur la problématique philosophique dans l'Afrique actuelle (Vol. 8). Editions Clé.

- Wiredu, K., Abraham, W. E., Irele, A., \& Ifeanyi, A. (Eds.). (2004). A companion to African philosophy. 